\title{
磁気シールドルームの開発と製造
}

\author{
山口孝夫* , 岩田英敏 ${ }^{*}$
}

\section{Development and Manufacturing of Magnetic Shielding Room}

\author{
Takao Yamaguchi and Hidetoshi Iwata
}

\section{Synopsis}

In recent years, SQUID (superconducting quantum interference device) technology has been developed for measuring the very low magnetic field generated from a human's physiology activity, and this technology is used for MEG (magnetencephalograph) and MCG (magnetcardiograph). In this way, the MEG and MCG have begun to be installed to the some hospitals as the medical devices. It is necessary to reduce the environmental magnetic field significantly, in order to measure the weak signals with high stability by using these devices.

We developed and manufactured the magnetic shielding room for this purpose. In this paper, shielding performance of the magnetic shielding room at the low intensity and low frequency magnetic field is introduced.

\section{1. 緒 言}

1963 年にはじめて生体から発する磁場が記録 ${ }^{1)}$ されて 以来，近年では超伝導磁気センサーである SQUID (Superconducting QUantum Interference Device) を用いて人体から 発生する微弱な磁場を計測する技術が実用化され，脳や心 蔵などの生理活動が, 人体には全くの無侵襲で脳磁図 (MEG: MagnetoEncephaloGraph) や心磁図 (MCG: MagnetoCardioGraph) としてマッピング可視化できるようになっ た。

また，2004 年 4 月の診療報酬点数表の改正 ${ }^{2)}$ によって 神経磁気診断が新規に採用され，健康保険が適用されるよ うになった .こうしたことから各地の病院には,脳の生理 活動を直接測定できる診断装置として脳磁計が導入され つつあり，微弱な脳磁を安定して計測するために磁場環境 を改善する装置として，磁気シールドルーム（MSR: Magnetic Shielding Room) が必需品となっている.

病院などに置かれる磁気シールドルームに要求される 特性としては主に次の 4 項目が挙げられる . (1) 低磁界, 低周波領域での高いシールド性能を有すること，(2) 極め て微弱な信号を扱うので超伝導磁気センサーや解析用コ ンピュータ機器類に光のケーブルも含めて EMC
(ElectroMagnetic Compatibility) 対策が施されていること， （3）シールド材が振動すると内部の磁場も振動するため, これら振動を測定して必要な防振対策が施されているこ と, (4) 診断を受ける患者はもちろんのこと, 診断や機器 の操作，介添などを行う医師，技師，看護師のために樣々 な安全性, 快適性, 利便性が考慮された居住空間を得るこ と.

これらの要求に対して実用に供する磁気シールドルー ムを開発し製造したので, 本稿では,とくに(1)の低磁界， 低周波領域での磁気シールド性能について, 弚の測定方法 も含めて紹介する .

\section{2 .磁気シールドの必要性と炎の評価}

\section{1 環境磁場ノイズ}

生体から発する磁場の一つとして,例えば脳磁は脳神経 細胞に流れるイオン電流から右ネジの法則によって発生 するものである. 弚の大きさは数十から数百 fT (fT: フェ ムトテスラ $10^{-15}$ テスラ) 程度 ${ }^{1)}$ と言われている.これ に対して, 都市部においては環境磁場ノイズは数百から数 千 nT (nT: ナノテスラ, $10^{-9}$ テスラ) である.すなわち， 脳磁は環境磁場ノイズの 1 千万分の1程度の大きさである．

Fig.1に磁気シールドルームの内部と外部の環境磁場ノ 
イズ ${ }^{3)}$ の例を示す.磁気シールドルームの外部の環境磁 場は, フラックスゲート式磁束計で測定した.地球磁場に よる磁力線は $1 / \mathrm{f}$ ゆらぎを持っているが，都市部にあって は電車や自動車などの磁性体が磁力線の中を横切ること によって発生する低周波の磁場のゆらぎや，送電線あるい は電車の架線や帰線電流などの巨大な電流ループによっ て発生する磁場，さらには建物の中にあっては, 空調の ファンやエレベータの稼動, 弚の他電気機器類の稼動に よって発生する人工的な磁場ノイズが重曽される．

光れらの例としてFig.2に昼夜連続して記録した磁場の

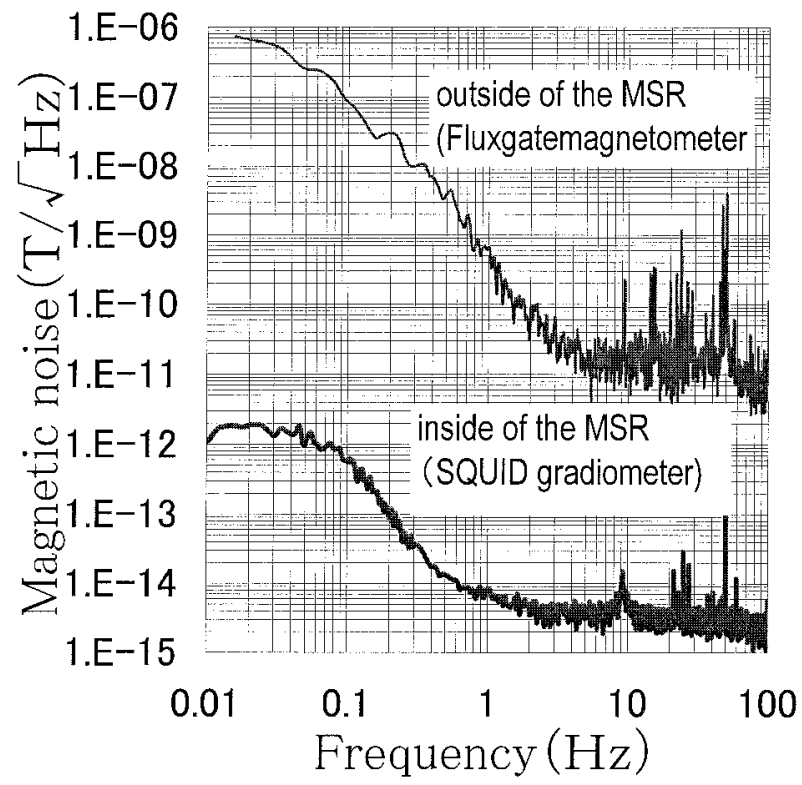

Fig.1. Magnetic noise level inside/outside of MSR (Magnetic Shielding Room).

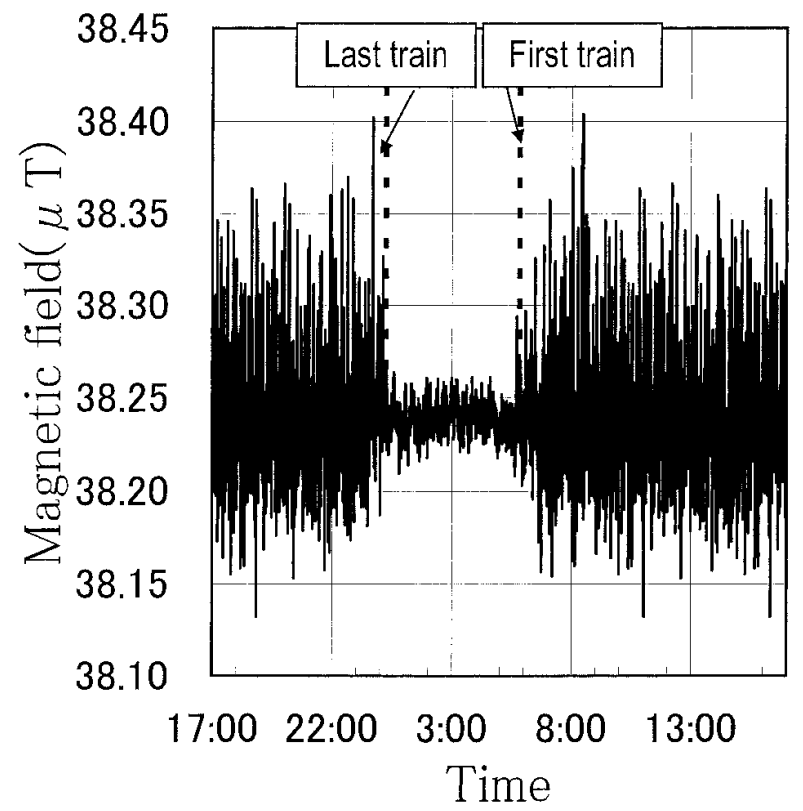

Fig.2. Variation of the DC magnetic field (geomagnetism) under the influence of a train and a track.
大きさの変化を示す .これは, 電車の線路から直線距離で 200 メートル離れた建物内部において 30 秒每に瞬時の直 流磁場 (地磁気) の大きさをフラックスゲート式磁束計で 測定したものである.電車の動いている時間帯の変動幅に 比べて, 電車が止まる夜中の 0 時から明け方 5 時半まで は, 弚の変動幅が小さことが分かる.

また , Fig.3 にエレベータの稼動による磁場の大きさの
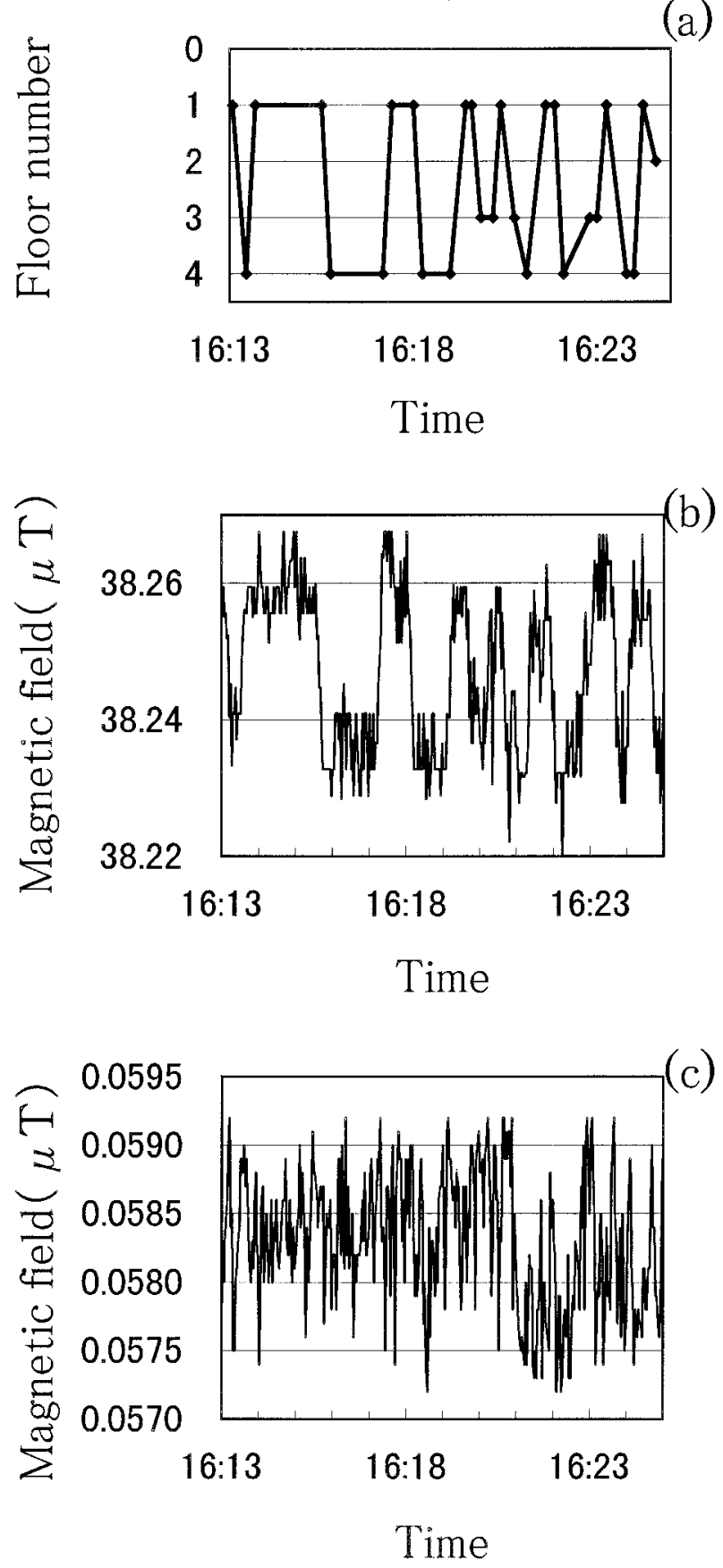

Fig.3. (a) Movement of the elevator which performed observation simultaneous with record of the magnetic field. (b) Variation of the DC magnetic field (geomagnetism) outside of the MSR under the influence of an elevator. (c) Variation of the DC magnetic field (geomagnetism) inside of the MSR under the influence of the elevator. 
変化を示す .これは建物内でエレベータから直線距離で 10 メートル離れた廊下で測定し, 磁束計の出力はパソコ ンで記録した .またエレベータが何階にいるか目視で確認 し，光の時刻を記録した .これらの記録は,パソコンの時 計とエレベータの観察者の時計の時刻を秒単位まで一致 させて行った .直流磁場の大きさの変化を示すグラフと並 記すると, 兴の変化がよく一致しており,エレベータの稼 動によって直流磁場か湾動していることが分かる.

以上に 2 つ例のみ示したが ,我々の周囲には環境磁場 ノイズが満ち溢れており，微弱な生体磁場を測定するため には，これらの磁場環境の改善が必要となってくる．

\section{2 磁気シールドの設計}

A.P.Wills によって球面と無限円筒の磁気シールドの理 論式 ${ }^{4)}$ がある．また V.O.Kelha らによって，立方体款など についての磁気シールドの近似式 5) がある .これらによ ると1層の磁気シールド材で覆われた立方体款の磁気シー ルド率は，

$$
\mathrm{S}=1+0.8(\mu \cdot \mathrm{t} / \mathrm{L})
$$

ここで, S: 磁気シールド率 $\mu$ : 磁気シールド材の比透磁率 $\mathrm{t}$ : 磁気シールド材の板厚 $\mathrm{L}:$ 立方体の 1 辺の長さ

て計算されている。

また 2 層，3 層の磁気シールド材で覆われている場合に は光れ光れ

$$
\begin{aligned}
\mathrm{S}=1+\mathrm{S}_{1}+\mathrm{S}_{2}+\mathrm{S}_{1} \mathrm{~S}_{2} \mathrm{~V}_{12} \\
\mathrm{~S}=1+\mathrm{S}_{1}+\mathrm{S}_{2}+\mathrm{S}_{3}+\mathrm{S}_{1} \mathrm{~S}_{2} \mathrm{~V}_{12}+\mathrm{S}_{1} \mathrm{~S}_{3} \mathrm{~V}_{13} \\
\quad+\mathrm{S}_{2} \mathrm{~S}_{3} \mathrm{~V}_{23}+\mathrm{S}_{1} \mathrm{~S}_{2} \mathrm{~S}_{3} \mathrm{~V}_{12} \mathrm{~V}_{13} \\
\text { ここで, } \quad \\
\mathrm{S}=1+0.8\left(\mu_{\mathrm{i}} \cdot \mathrm{t}_{\mathrm{i}} / \mathrm{L}_{\mathrm{i}}\right), \quad \mathrm{i}=1,2,3 \\
\mathrm{~V}_{\mathrm{ij}}=1-\left(\mathrm{L}_{\mathrm{i}} / \mathrm{L}_{\mathrm{j}}\right)^{3}, \quad \mathrm{i}, \mathrm{j}=1,2,3
\end{aligned}
$$

見出し文字 $\mathrm{i}, \mathrm{j}$ は最内層の款から振る

これらの式によれば,シールド率 S はシールド材の透磁 率 $\mu$ と板厚 $\mathrm{t}$ に比例し, シールドルームの大きさ $\mathrm{L}$ には 反比例することが分かる.また，シールド層を多層にする ほど , シールド率 S が上がることが分かる.さらには,多 層にした場合,層と層の間の距離を大きくとる方がシール ド率 S が上がることも分かる .

透磁率の高い材料としてパーマロイ (JIS C2531 PC 相当 材)を用いて磁気シールドルームを設計し製造する場合に おいて, (1)〜 (3) の式で, シールド材の板厚 $\mathrm{t}$ とシールド ルームの大きさ L は任意に設定できる . パーマロイの透 磁率 $\mu$ は,例えば製造ロット毎にJIS C 2531 によって規定 された方法で測定されているが, 製造時の曲げや切断，穴 あけ加工によって透磁率は極端に劣化するので熱処理 6) を行なって回復させても,元の值を再出できるとは限ら

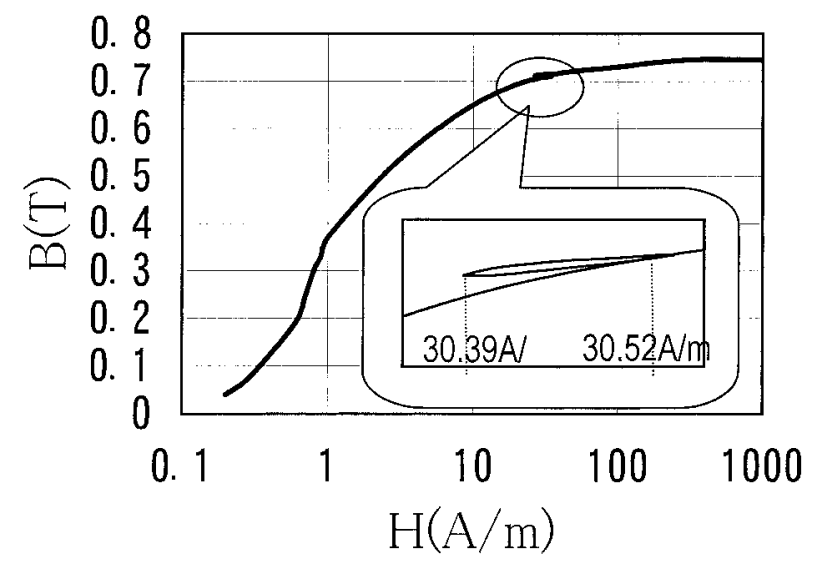

Fig.4. Variation of the environmental magnetic field plotted on the permalloy $\mathrm{BH}$ curve.

ず,磁気シールドルームを製造した後において保証され得 る数值ではないので, 任意の数值を入れることは出来な い.

また ,パーマロイの直流磁化曲線 ${ }^{6}$ の中で見た場合, 外 部環境磁場の変動が小いということがある.例えば電車 による地磁気の変動は, Fig.2 に示した例の場合, 約 $38.17 \mu \mathrm{T}(=30.39 \mathrm{~A} / \mathrm{m})$ から約 $38.33 \mu \mathrm{T}(=30.52 \mathrm{~A} / \mathrm{m})$ の間で変 動している .この電車による変動磁場をパーマロイの直流 磁化曲線の中に記すと Fig.4 となり, 最大透磁率 $\mu \mathrm{m}$ より もはるかに小さい勾配となっていることが分かる .

磁気シールドの設計を行う場合, 磁気シールドルームの サイズ L は設置場所や内部に置く脳磁計などから経済的 なサイズが決定される.磁気シールド率 $\mathrm{S}$ は, 外部の環境 磁場や内部に置く装置 (脳磁計など) の性能から決定され る.これに応じてシールド材の板厚, 層の数も決められる が, 経済的な数值でなければならない, 板厚を厚くし，ま た層数を多くすれば, 高い磁気シールド率が得られるが， 重量か増しコスト高になるばかりでなく,設置場所の床耐 過重増強の処置などが必要となる場合もある こうしたこ とから,なるべく磁気シールド材の板厚を薄くし, 層数も 少なくしたい，弚のためには磁気シールドルームが完成し た後の最大透磁率よりも小さい勾配 (実際の透磁率 $\mu$ ) を 精密に見込んで設計されなければならない .

\section{3 磁気シールドの測定方法}

磁気シールド率 S は, 内部磁界 $\mathrm{Hi}$ と外部磁界 $\mathrm{He}$ の比 ${ }^{7)}$ で表される .

$$
\mathrm{S}=\mathrm{He} / \mathrm{Hi}
$$

例えば，エレベータが稼動したとき，Fig.3(b) に示す外 部磁界に対して，Fig.3(c) に示す内部磁界となる .この例 では, 外部磁界が約 $38 \mu \mathrm{T}$ であるのに対して, 内部磁界 が約 $0.058 \mu \mathrm{T}$ であることから, 磁気シールド率 $\mathrm{S}$ は, $38 /$ 
0.058=650 となる. また, 変動幅に着目すると, 外部磁界 は $38.23 \mu \mathrm{T}$ から $38.27 \mu \mathrm{T}$ の間で変動しており, 変動幅は $0.04 \mu \mathrm{T}$ である .これに対して内部磁界は $0.0572 \mu \mathrm{T}$ から $0.0592 \mu \mathrm{T}$ の間で変動しており, 変動幅は $0.002 \mu \mathrm{T}$ とな る.すなわち, 変動幅から磁気シールド率を算出すると $\mathrm{S}$ は , $0.04 / 0.002=20$ となる. また, シールドの内部磁界と 外部磁界は同一時間で測定していても, 空間的には異なる 場所の測定をしており，再現性のある值とは言いがたく， 磁気シールドの検査を行うときなどには，こういった值は 用いにくい.

磁気シールドルームの測定方法に関しては，1994 年超 伝導センサー研究所に「COSMOS」と命名された超高性 能磁気シールドルームか設置され, 光の磁気シールド率の 測定方法が検討されている ${ }^{8)}$. これは球体に近い 32 面体 構造をし最外形 $6100 \mathrm{~mm}$ のサイズの4 層パーマロイ構造で 総重量約 $40 \mathrm{t}$ であり単位面積あたりの荷重は $1 \mathrm{t} / \mathrm{m}^{2}$ を超 え, 設置場所の床は特別な補強が行われている.外部に置 いた直径 $2000 \mathrm{~mm}$ のコイルで $1 \mathrm{~Hz}$ と $12 \mathrm{~Hz}$ の正弦波磁界を 発生させ , 光の磁場を磁気シールドルーム内部に置いた SQUID磁束計で磁束密度 $(\mathrm{Hi})$ を測定し, 磁気シールドルー ムが無いときの SQUID 磁束計の位置での磁束密度 $(\mathrm{He})$ を
計算によって求めて，これらの比 $(\mathrm{He} / \mathrm{Hi})$ からシールド 率を算出し，1Hzでは $420700 ， 12 \mathrm{~Hz}$ では 1282000 という 非常に高い磁気シールド率が得られている.

さらには, 山崎ら ${ }^{9)}$ によって , 外部磁界印加用のコイ ルの寸法や配置, 磁気シールドルームからの隔離距離が磁 気シールド率の評価結果に与える影響があるとして, 遠方 から到来する一樣な磁場ノイズに対する磁気シールド率 と，磁気シールドルームの近傍で発生する不均一な磁場ノ イズに対する磁気シールド率の 2 種類では, 光れ光れ異 なった結果になることの検討が行われている .

\section{4 磁気シールドの製造と評価}

2 層パーマロイ構造の磁気シールドルームを実際に設計 製造し評価を行った . 2 層パーマロイ構造のものは, 内寸 で奥行 $2300 \mathrm{~mm}$, 幅 $2100 \mathrm{~mm}$, 高さ $2100 \mathrm{~mm}$ とし, パーマ ロイとパーマロイの層間は $100 \mathrm{~mm}$ とした .これは, 磁気 シールドルームとしての構造体を保持するものとしてア ルミ (A6063) 角パイプー般品の一つである 100mm 角を切 断, 溶接してフレーム構造として, 乥こにパーマロイを透 磁率の低下しないように注意を払ってネジ止めで取り付 けていく . パーマロイは, 内外各々 $1.8 \mathrm{~mm}$ の厚さとした . その外観をFig.5 に示す.この磁気シールド率を 2 種類の

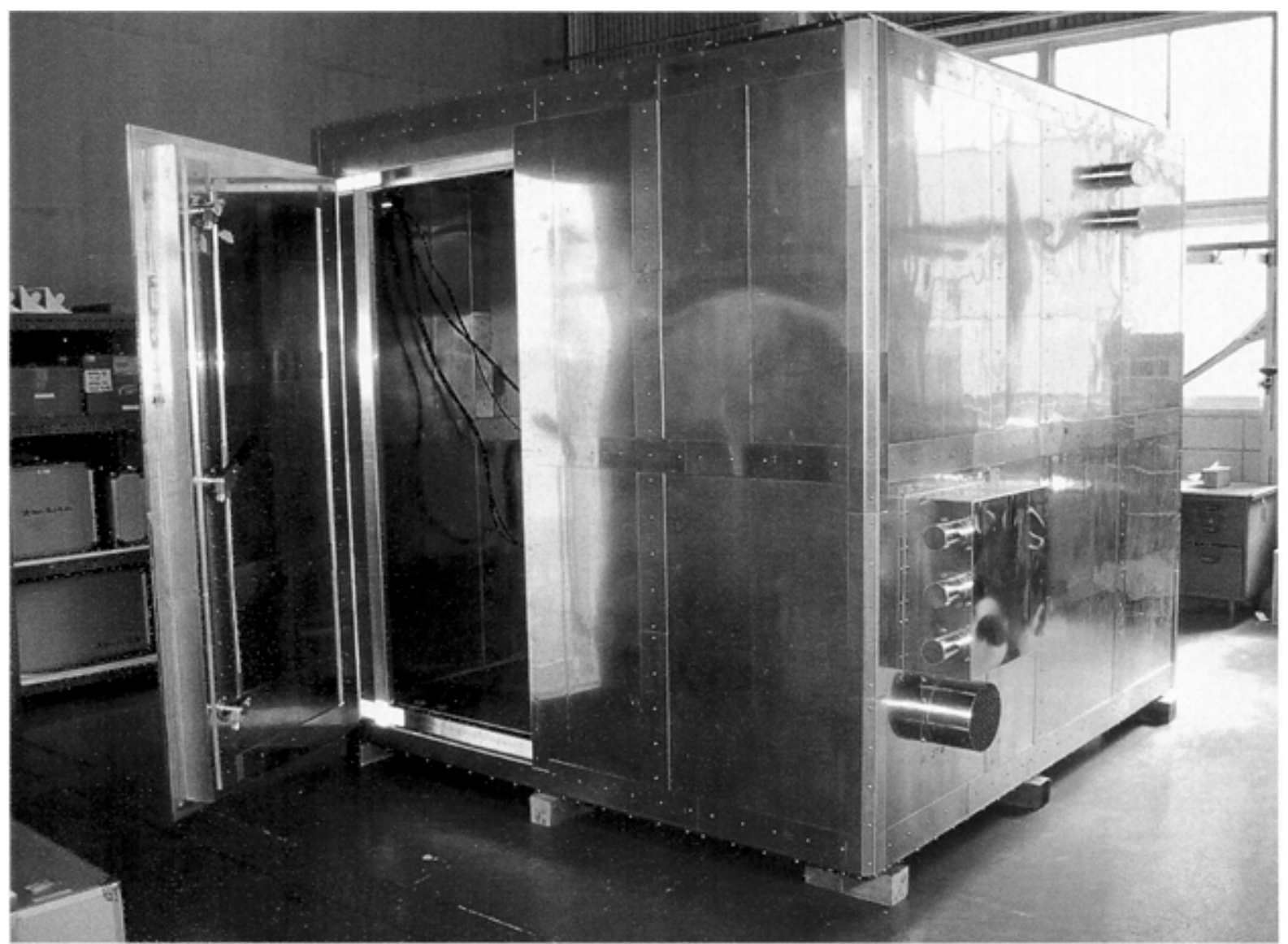

Fig.5. Appearance of the MSR. 
方法で測定した . 1 つは磁気シールドルームの対向する側 面に沿う形で電線を配接しコイルとした .これを仮に大コ イルと呼ぶ .もう 1 つは直径 $1200 \mathrm{~mm}$ の円形コイルで可動 式のものとした .これを仮に小コイルと呼ぶ . 兴のレイア ウトをFig.6に示す . このとき磁気シールドルームが無い 状態でコイルのみ有る場合も作り，乥こで測定した磁界を 外部磁界 $\mathrm{He}$ とした .

このとき，小コイルの位置を変えてコイル〜センサー間 の距離を変えて測定した結果をFig.7 に示す.距離か離れ るほど磁気シールド率が低下していることが,この例の場 合では4550mm以上離れると磁気シールド率が安定化して いる .

コイルか離れた場合は, 磁気シールドルームに印加され る磁場が小さくなることから, 磁場の大きさが磁気シール

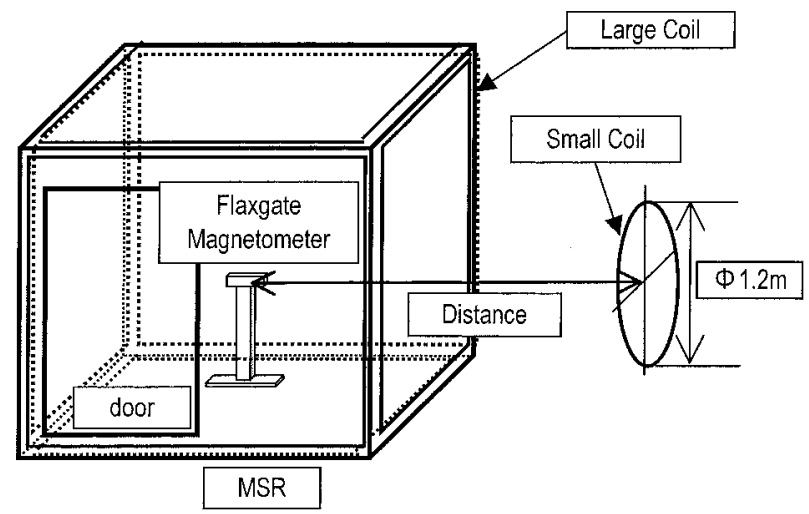

Fig.6. Layout of the MSR and the coil for the measurement system of the magnetic shielding factor.

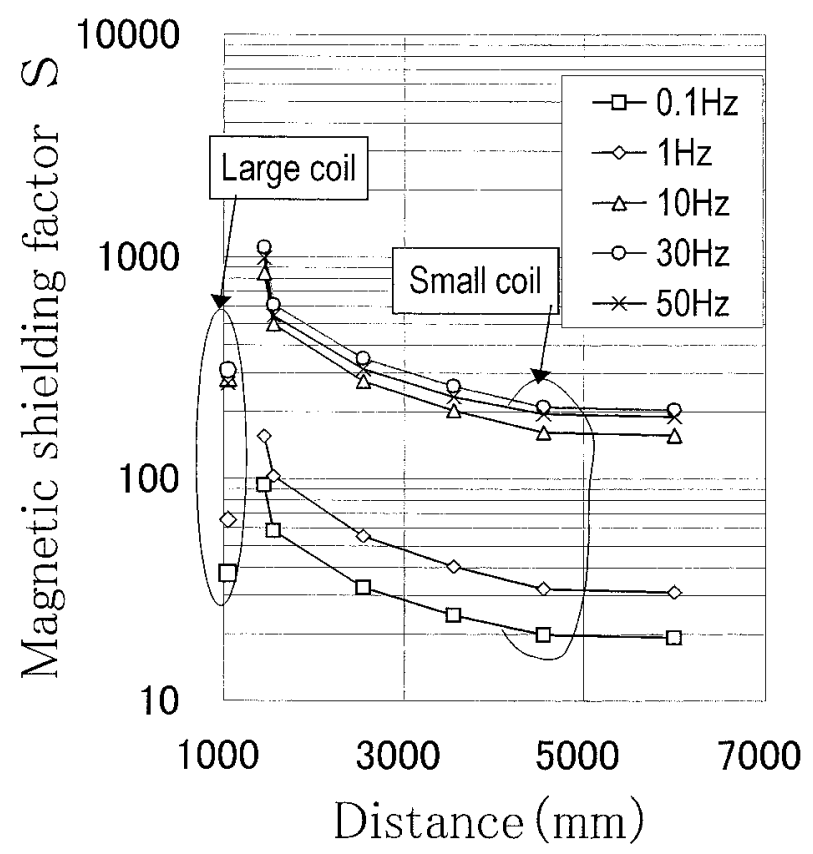

Fig.7. Relation between the magnetic shielding factor and the distance of the coil to the MSR.
ド率に与える影響も見ておく必要がある.乥こで小コイル の位置を一定とし，乥れに流す電流を変えることで, 磁場 の大きさを変えてみた場合がFig.8である.磁場の大きさ はコイル中心部のものである . 周波数が低いとき, 例えば $1 \mathrm{~Hz}$ のとき, 周波数の増大に伴って緩やかにシールド率 S は増えてはいるが, 弚の変化は少ない.すなわち, 小コイ ルが磁気シールドルームから離れていくと,小コイルから 発した磁界が一樣な磁場ノイズに近づいていくものと推 定される。

また , この例での大コイルでの磁気シールド率は, 小コ イルか距離 $2550 \mathrm{~mm}$ のとろにある場合と同じ程度になっ ている.したがって大コイルでの磁気シールド率は, 一樣 な磁場ノイズに対する磁気シールド率よりも大きめの值 となり，近傍で発生する不均一な磁場ノイズに対する磁気 シールド率よりも小さめの值となる .

実際の磁気シールドルームは, 空間的に制約のある建物 内に設置されることがほとんどである．すなわち，磁気 シールドルームの外壁や屋根部分は, 建物の部屋の内壁や 天井と密着するように設置されることが多い.こうしたこ とから，測定に用いるコイルの配置も制約を受けるので， 測定のために任意の位置にコイルを設置できない場合が 多い.

乥こで某大学に設置した脳磁研究用の3層パーマロイ構 造の磁気シールドルームの例を示す . 3 層パーマロイの厚 みは最内層から外層に向かって順番に $4 \mathrm{~mm}, 2 \mathrm{~mm}, 2 \mathrm{~mm}$ である 内忖は奥行 $3500 \mathrm{~mm} \times$ 幅 $2300 \mathrm{~mm} \times$ 高さ $1990 \mathrm{~mm}$ ，

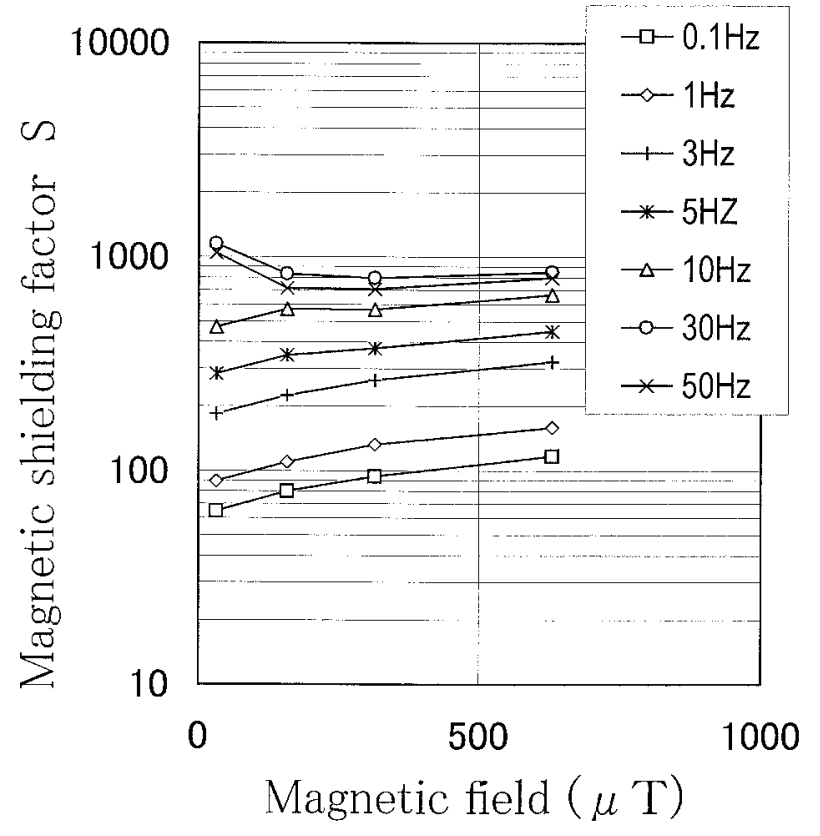

Fig.8. Relation between the magnetic shielding factor and the coil current (magnetic field of the coil). 

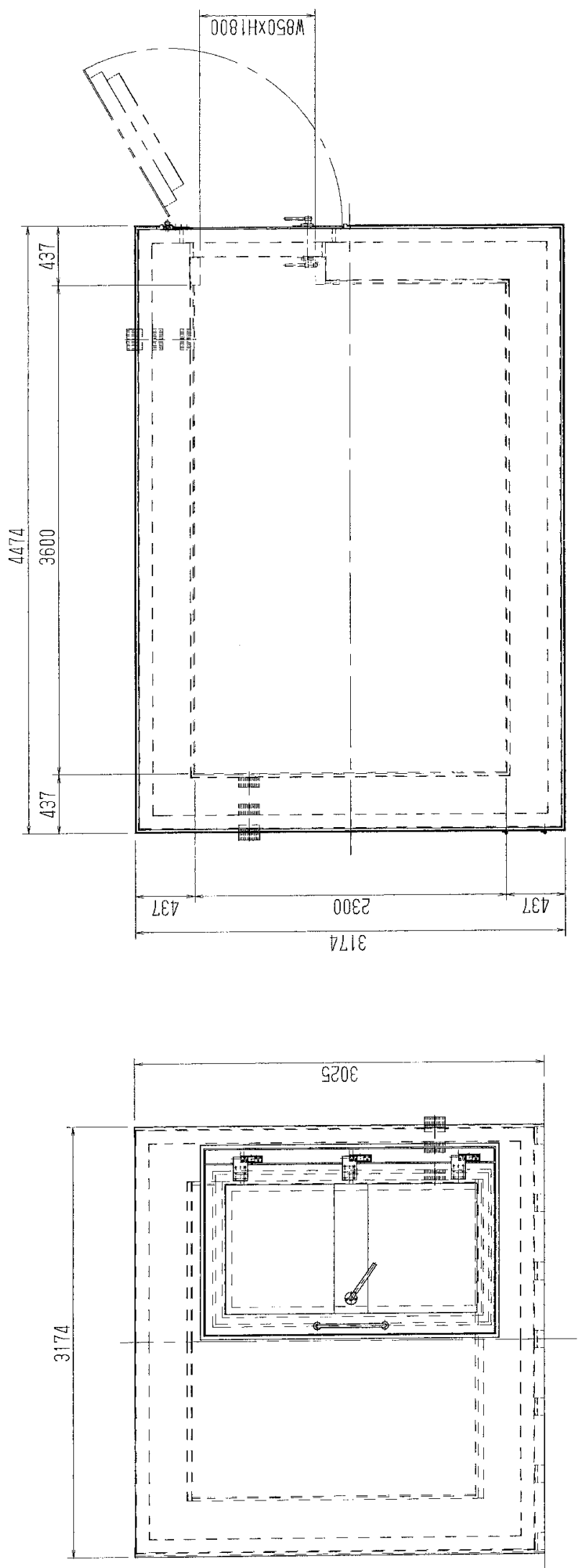

Fig.9. The magnetic shielding factor of the MSR which is threelayer permalloy structure.

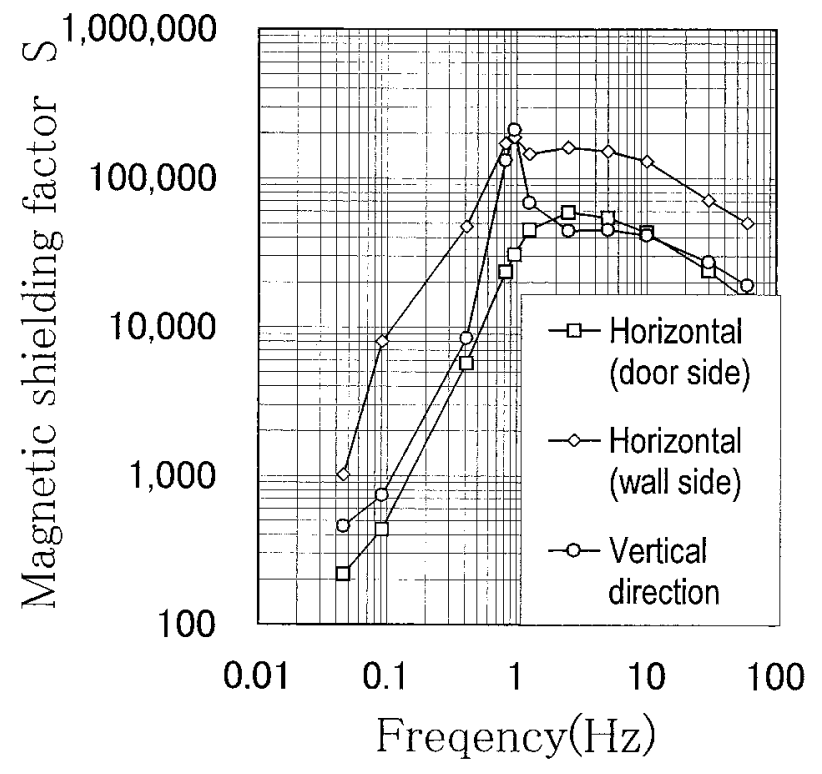

Fig.10. The outside drawing of the three-layer magnetic shielding room.

外寸は奥行 $4350 \mathrm{~mm} \times$ 幅 $3180 \mathrm{~mm} \times$ 高さ $2880 \mathrm{~mm}$ であり， 総重量は約 $7 \mathrm{t}$ ，単位面積あたりの荷重は $510 \mathrm{~kg} / \mathrm{m}^{2}$ とな る. 产の外形图をFig.9 に示す.

この磁気シールドルームの稜線部に大コイルを取り付 けた . この大コイルはビニール被覆の 10 芯のケーブルを 用い, 磁気シールドルームの䨿面〜背面方向, 左側面〜右 側面 ,天井〜床方向の3つの方向に乥れ磁界が印加さ れるように配置した . 产れらの測定結果をFig.10 に示し た . $1 \mathrm{~Hz}$ の磁気シールド率は, 扉面〜背面の方向に磁界を 印加した場合が最も低いが 30000 , 弚の他の方向に磁界を 印加した場合が 100000 以上のシールド率を得た .また SQUID センサーで測定した磁気シールドルーム内部の環 境磁場ノイズを Fig.1 に示す.例えば $1 \mathrm{~Hz}$ において約 5 桁 ほど，外部の環境磁場ノイズよりも低くなっている．

\section{3.まとめ}

低周波低磁界での高い磁気シールド率 (30000 以上) を 確保しつつ, 従来のものよりも軽量化した磁気シールド ルームを開発し製造した。

また ,乥の磁気シールド率を再現性よく正確に測定する 手法として, 実際に磁気シールドルームが設置されるス ペースも考慮して, 磁気シールドルームの稜線部に多芯 ケーブルを張り，光こに磁界を印加して磁気シールド内部 の磁界を測定し,あらかじめ磁気シールドルームが無い場 合の合同形でのケーブルで測定した外部磁界と比較する ことによって磁気シールド率を測定した . 
(文 献)

1) 原宏 栗城真也: 脳磁気科学 SQUID計測と医学応用(オー 么社), (1997), 6.

2) 厚生労働省ホームページ: http://202.214.127.149/smente 040308.pdf.

3)風見邦夫，春田康博，山口孝夫:日本生体磁気学会誌特別 号16(2003), 1, 100.

4) A. P. Wills: Phy. Rev., (1899), 193.

5) Vaino O. Kelha: IEEE Trans. Magn., 18(1982), 1, 262.

6)大同特殊鋼技術資料: № KD8211bパーマロイ, (2002), 3.

7) Albrecht J. Mager: IEEE Trans. Magn., 6(1970), 1, 67.

8) 原川健一梶原暁, 風見邦夫, 尾形久直: 電気学会研究会 資料1M-94(1994), 17.

9) 山崎慶太, 藤原耕二, 他: 電気学会論文集, A118(1998), 5, 453. 